\title{
Body Resistance and Growth Performance of Broiler Fed Glucomannan Extracted from Amorphophallus onchophyllus Tuber
}

\author{
A. Perdinan*, H.I. Wahyuni, \& N. Suthama \\ Faculty of Animal and Agricultural Sciences, Diponegoro University \\ Tembalang Semarang 50275, Central Java, Indonesia \\ *Corresponding author: acepperdinan@yahoo.com \\ (Received 15-08-2018; Revised 26-10-2018; Accepted 03-12-2018)
}

\begin{abstract}
The purpose of the study was to examine the supplementation effects of glucomannan extracted from a porang tuber (GEPT) on body resistance and growth performance of broiler chickens. A total number of 160 one-day-old broiler chickens with the average body weight of $42.39 \pm 0.58 \mathrm{~g}$ was kept for 35 days. The study was arranged in a completely randomized design with 5 treatments and 4 replications ( 8 birds each). The dietary treatments were $\mathrm{T} 0=$ basal ration, $\mathrm{T} 1=$ basal ration with the addition of $0.05 \%$ GEPT, T2= basal ration with the addition of $0.1 \%$ GEPT, T3= basal ration with the addition of $0.15 \%$ GEPT, and T4= basal ration with the addition of $0.2 \%$ GEPT. Parameters measured were the population of lactic acid bacteria (LAB), Coliform count, relative weight of lymphoid organs (bursa fabricius and spleen), heterophils-lymphocytes (H/L) ratio, body weight gain, feed consumption, feed conversion ratio, and mortality. Data were subjected to analysis of variance (ANOVA) and continued with Duncan Multiple Range Test (DMRT) at 5\% probability. The results showed that supplementation of the diets with GEPT significantly increased $(P<0.05)$ LAB population, decreased $(\mathrm{P}<0.05)$ Coliform count in the jejunum and ileum, and $\mathrm{H} / \mathrm{L}$ ratio, but did not affect the relative weight of lymphoid organs, and growth performance. In conclusion, diet added with $0.1 \%$ GEPT improved the balance of intestinal microflora and increased body resistance, without any negative effects on the lymphoid organs and growth performance of broiler chickens.
\end{abstract}

Keywords: body resistance; broiler chickens; glucomannan; growth performance; porang tuber extract

\section{INTRODUCTION}

The current poultry industry is not only focused on the increasing production in quantity but also it aims to produce a healthy product for consumers. Feeding dietary additive was one of the efforts that could be implemented to increase poultry production either quantitatively or qualitatively. Recently, natural feed additives without gaining residue in the product are the most commonly popular and useful for poultry production. Prebiotic is a natural feed additive that has been widely used over the last three decades as an alternative to antibiotics because prebiotic had no negative effects on product quality and consumer health. Prebiotic was defined as a non-digestible compound that could be metabolized by the gastrointestinal microorganisms and modulated the improvement of bacterial composition and activity. These functions could provide a positive physiological effect on host condition (Bindels et al., 2015).

Feeding prebiotic was expected to maintain the balance of gastrointestinal microbes by suppressing the growth of pathogenic bacteria and stimulating the development of beneficial bacteria (Kim et al., 2011). Therefore, it could increase health status (Bozkurt et al., 2014) and improve the production performance of broiler chickens (Mateova et al., 2008). Prebiotic also indicated a high ability to interfere the harmful bacteria via the competitive exclusion status on pathogenic bacteria and selective colonization of beneficial bacteria (Pourabedin et al., 2015).

Natural prebiotic used in the present study was glucomannan derived from porang (Amorphophallus onchophyllus) tuber extract. Porang (A. onchophyllus) is an Indonesian local plant that produces tubers containing 50\%-65\% glucomannan (Yanuriati et al., 2017). Glucomannan consisted of D-glucose monomers and D-mannose units linked by $\beta$-1,4-glycosidic bonds (Tester \& Al-Ghazzewi, 2013). Glucomannan could be fermented by endogenous beneficial bacteria, especially lactic acid bacteria $\mathrm{LAB}$, to produce short-chain fatty acids, namely acetic acid, butyric acid, and propionic acid in the caeca (Pourabedin \& Zhao, 2015). Short chain fatty acids exerted its effect by decreasing the $\mathrm{pH}$ of the gastrointestinal tract and thus inhibiting the growth of pathogenic bacteria. The balance of intestinal microflora caused a healthier digestive tract in poultry. In poultry, the health status of gastrointestinal tract related to the presence of SCFA product was associated with the inhibition of pathogenic bacteria colonization in the intes- 
tine and affected metabolic regulation (Meimandipour et al., 2011; Pourabedin \& Zhao, 2015).

The balance of intestinal microflora could be connected with the increase in body resistance and productivity. Intestinal microflora played an important role in the health and productivity of broiler chickens, associated with the morphology of the gastrointestinal tract, absorption of nutrient, and immunity (Kohl, 2012). Several strains of LAB could stimulate body resistance with dendritic cell signal for the activation of $\mathrm{T}$ cell and B cell to produce antibody (Pourabedin \& Zhao, 2015). Bursa fabricius and thymus were two organs responsible for the maturation and differentiation of B lymphocyte and $\mathrm{T}$ lymphocyte, respectively, in the primary lymphoid organs. These physiological mechanisms could be understood via their effects on $\mathrm{H} / \mathrm{L}$ ratio as an indication of stress level in the broiler (Ruminska et al, 2008; Hosseini et al., 2016). Body resistance as the indicator of response to the adverse effect of environmental condition or infectious disease might be reflected by the relative weight of lymphoid organs and $\mathrm{H} / \mathrm{L}$ ratio. Higher body resistance and healthier gastrointestinal tract due to prebiotic feeding effect could improve nutrient uptake, thus increase broiler performance. Studies concerning the effect of prebiotics in general on poultry production performance have been conducted previously elsewhere, however, information in relation to feeding glucomannan extract derived from porang tuber, in particular, are almost not available. Therefore, the purpose of this study was to examine the effects of dietary supplementation with glucomannan extracted from porang tuber (GEPT) on body resistance and growth performance of broiler chickens.

\section{MATERIALS AND METHODS}

\section{Animal and Ration}

One hundred and sixty (160) birds of one-day-old Lohmann strain of broilers with an average initial body weight of $42.39 \pm 0.58 \mathrm{~g}$ were used in the current study. The basal ration was composed of yellow corn, rice bran, soybean meal, meat bone meal (MBM), poultry meat meal (PMM), dicalcium phosphate (DCP), calcium carbonate (CaCO3), premix, L-lysine, and DL-methionine (Table 1). Energy and protein contents of the basal ration were $2965.69 \mathrm{kcal} / \mathrm{kg}$ and $21.33 \%$, respectively. Glucomannan was extracted from porang (Amorphopallus onchophyllus) tuber-based on the method as described by Harmayani et al. (2014). Dietary treatments were given from day 1 to day 35. Ration and drinking water were provided ad libitum. Throughout the experimental period, the experimental birds were only provided commercial Newcastle Disease Virus (NDV) vaccine through eye drops and drinking water on days 4 and 20 of the experiment, respectively.

\section{Slaughtering Procedure and Sampling}

Four birds from each treatment were randomly selected for blood and digest collections. Blood was obtained from the branchialis veins of birds' wing and placed in vacutainers containing ethylene diamine tetra acetic acid (EDTA) as an anticoagulant for heterophil and lymphocyte analysis. After being weighed, the same birds from which blood was sampled were slaughtered. Bursa fabricius and spleen were immediately removed and weighed. The intestinal digests were carefully expelled by squeezing from the jejunum and ileum into the tightly sealed of sterile sample bottles for LAB and Coliform analysis.

\section{Variable Determination Procedure}

Populations of LAB and Coliform were calculated based on Standard Plate Count (SPC) method according to Fardiaz (1993). Lactic Acid Bacteria were enumerated on de Man, Rogosa and Sharpe (MRS; Oxoid) agar after anaerobic incubation at $37^{\circ} \mathrm{C}$ for $48 \mathrm{~h}$. Coliform bacteria were counted on MacConkey agar (Oxoid) following aerobic incubation at $37^{\circ} \mathrm{C}$ for $24 \mathrm{~h}$ as red colonies. The $\mathrm{H} / \mathrm{L}$ ratio was determined by dividing the number of heterophils with the number of lymphocytes (Gross \& Siegel, 1983). The relative weight of lymphoid organs was measured based on the ratio of lymphoid organ weight and live weight of the chicken multiplied by $100 \%$. Feed consumption and mortality were recorded daily, and the calculation was based on the accumulated amount at the end of the experiment. Feed conversion ratio was obtained by dividing feed consumption with the body weight gain.

Table 1. Composition and nutrient contents of basal diet

\begin{tabular}{|c|c|}
\hline Feedstuff & Composition $(\%)$ \\
\hline Yellow corn & 54.00 \\
\hline Rice bran & 14.20 \\
\hline Soybean meal & 18.00 \\
\hline Meat bone meal & 5.75 \\
\hline Poultry meat meal & 6.75 \\
\hline Dicalcium phosphate & 0.50 \\
\hline L-Lysine & 0.10 \\
\hline DL-Methionine & 0.20 \\
\hline Calcium carbonate & 0.25 \\
\hline Premix & 0.25 \\
\hline Total & 100.00 \\
\hline \multicolumn{2}{|l|}{ Nutritional content } \\
\hline Metabolizable energy $(\mathrm{kcal} / \mathrm{kg}){ }^{*}$ & 2965.69 \\
\hline Crude protein ${ }^{* *}$ & 21.33 \\
\hline Ether extract ** & 4.68 \\
\hline Crude fiber** & 4.45 \\
\hline Calcium** & 1.03 \\
\hline Phosphorus ${ }^{* *}$ & 0.71 \\
\hline Methionine ${ }^{* * *}$ & 0.55 \\
\hline Lysine ${ }^{* * *}$ & 1.16 \\
\hline \multicolumn{2}{|c|}{ 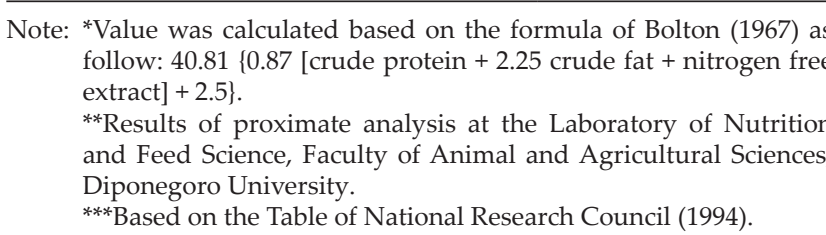 } \\
\hline
\end{tabular}




\section{Experimental Design and Variables Measured}

The present study was arranged in a completely randomized design (CRD) with 5 treatments and 4 replications ( 8 birds each). The dietary treatments tested were as follows: $\mathrm{T} 0=$ basal ration without $\mathrm{GEPT}, \mathrm{T} 1=$ basal ration with the addition of $0.05 \%$ GEPT, T2= basal ration with the addition of $0.1 \%$ GEPT, $\mathrm{T} 3=$ basal ration with the addition of $0.15 \%$ GEPT, and $\mathrm{T} 4=$ basal ration with the addition of $0.2 \%$ GEPT. Parameters measured were lactic acid bacteria (LAB) and Coliform populations in the jejunum and ileum, the relative weight of lymphoid organs (bursa fabricius and spleen), H/L ratio, body weight gain (BWG), feed consumption (FC), feed conversion ratio (FCR), and mortality. Data were collected on day 35 and statistically analyzed using analysis of variance (ANOVA) and continued with Duncan Multiple Range Test (DMRT) at 5\% probability (Steel \& Torrie, 1991).

\section{RESULTS}

\section{Intestinal Microflora}

Dietary supplementation of glucomannan derived from porang (Amorphophallus onchophyllus) tuber extract (GEPT) significantly increased $(\mathrm{P}<0.05)$ LAB population and decreased $(\mathrm{P}<0.05)$ Coliform in the jejunum and ileum. The highest jejunal and ileal LAB popula- tion was found in $0.1 \%$ GEPT (T2) (Table 2). However, the population of $\mathrm{LAB}$ due to supplementation effect of GEPT at $0.15 \%$ (T3) and $0.2 \%$ (T4) GEPT were significantly $(\mathrm{P}<0.05)$ higher than $\mathrm{T} 0$, but lower than $\mathrm{T} 1$ and T2. Coliform counts in jejunum and ileum significantly decreased $(\mathrm{P}<0.05)$ by supplementation of GEPT at any levels as compared to control (T0), but the lowest population was found in $\mathrm{T} 2$ treatment.

\section{Body Resistance and Growth Performance}

Supplementation of diets with GEPT did not significantly affect the relative weight of lymphoid organs (Table 3). However, $\mathrm{H} / \mathrm{L}$ ratio was significantly $(\mathrm{P}<0.05)$ lower with GEPT supplementation. The H/L value of T0 was the highest and significantly $(\mathrm{P}<0.05)$ different from the other GEPT treatments. There was no significant $(\mathrm{P}>0.05)$ difference on FBW, FC, and FCR due to the dietary treatments. It was observed that no mortality was found in broiler chickens treated with T2 until T4, whereas mortality at the rate of $3.12 \%$ was found in T0 and $\mathrm{T} 1$ treatments.

\section{DISCUSSION}

\section{Intestinal Microflora}

The results showed that GEPT supplementation stimulated LAB growth and reduced Coliform popula-

Table 2. Lactic acid bacteria and Coliform populations in the jejunum and ileum of broiler chickens fed diet supplemented with glucomannan extracted from porang tuber (GEPT)

\begin{tabular}{lccccc}
\hline \multirow{2}{*}{ Variables } & \multicolumn{5}{c}{ Treatments } \\
\cline { 2 - 6 } & T0 & T1 & T2 & T3 & T4 \\
\hline LAB $\left(10^{8} \mathrm{cfu} / \mathrm{g}\right)$ & & & & \\
$\quad$ Jejunum & $2.30 \pm 0.19^{\mathrm{d}}$ & $45.25 \pm 3.75^{\mathrm{b}}$ & $93.75 \pm 4.65^{\mathrm{a}}$ & $23.38 \pm 3.20^{\mathrm{c}}$ & $25.73 \pm 4.15^{\mathrm{c}}$ \\
$\quad$ Ileum & $3.83 \pm 0.70^{\mathrm{d}}$ & $59.00 \pm 3.74^{\mathrm{b}}$ & $108.00 \pm 4.32^{\mathrm{a}}$ & $36.20 \pm 4.26^{\mathrm{c}}$ & $39.40 \pm 4.22^{\mathrm{c}}$ \\
Coliform $\left(10^{3} \mathrm{cfu} / \mathrm{g}\right)$ & & & & & \\
$\quad$ Jejunum & $62.00 \pm 4.55^{\mathrm{a}}$ & $27.18 \pm 4.03^{\mathrm{c}}$ & $19.30 \pm 4.04^{\mathrm{d}}$ & $35.00 \pm 4.76^{\mathrm{b}}$ & $34.50 \pm 3.87^{\mathrm{b}}$ \\
$\quad$ Ileum & $54.25 \pm 2.99^{\mathrm{a}}$ & $11.90 \pm 0.71^{\mathrm{c}}$ & $7.60 \pm 0.59^{\mathrm{d}}$ & $27.75 \pm 2.50^{\mathrm{b}}$ & $25.15 \pm 2.34^{\mathrm{b}}$ \\
\hline
\end{tabular}

Note: Means in the same row with different superscripts differ significantly $(\mathrm{P}<0.05)$. T0= basal ration without GEPT; T1= basal ration $+0.05 \%$ GEPT; $\mathrm{T} 2=$ basal ration $+0.1 \%$ GEPT; $\mathrm{T} 3=$ basal ration $+0.15 \%$ GEPT; $\mathrm{T} 4=$ basal ration $+0.2 \%$ GEPT.

Table 3. Body resistance and growth performance of broiler chickens given diet supplemented with glucomannan extracted from porang tuber (GEPT)

\begin{tabular}{lccccc}
\hline \multicolumn{1}{c}{ Variables } & \multicolumn{5}{c}{ Treatments } \\
\cline { 2 - 6 } & T0 & T1 & T2 & T3 & T4 \\
\hline Body resistance & & & & & \\
$\quad$ Bursa fabricius weight (\%) & $0.185 \pm 0.01$ & $0.209 \pm 0.01$ & $0.201 \pm 0.03$ & $0.203 \pm 0.01$ & $0.202 \pm 0.01$ \\
Spleen weight (\%) & $0.105 \pm 0.02$ & $0.088 \pm 0.01$ & $0.090 \pm 0.02$ & $0.091 \pm 0.01$ & $0.093 \pm 0.01$ \\
H/L ratio & $0.600 \pm 0.22^{\mathrm{a}}$ & $0.290 \pm 0.07 \mathrm{~b}$ & $0.270 \pm 0.03^{\mathrm{b}}$ & $0.280 \pm 0.08^{\mathrm{b}}$ & $0.300 \pm 0.01^{\mathrm{b}}$ \\
Growth performance & & & & & \\
Body weight gain (g/bird) & $1445.10 \pm 80.11$ & $1497.40 \pm 117.92$ & $1522.80 \pm 90.16$ & $1468.70 \pm 80.64$ & $1481.90 \pm 111.23$ \\
Feed consumption (g/bird) & $2449.06 \pm 69.19$ & $2396.49 \pm 95.18$ & $2503.74 \pm 85.45$ & $2409.76 \pm 138.74$ & $2461.81 \pm 69.19$ \\
Feed conversion & $1.69 \pm 0.01$ & $1.61 \pm 0.05$ & $1.65 \pm 0.04$ & $1.64 \pm 0.04$ & $1.67 \pm 0.03$ \\
Mortality (\%) & 3.12 & 3.12 & 0 & 0 & 0 \\
\hline
\end{tabular}

Note: Means in the same row with different superscripts differ significantly $(\mathrm{P}<0.05)$. T0= basal ration without GEPT; T1= basal ration $+0.05 \%$ GEPT; $\mathrm{T} 2=$ basal ration $+0.1 \%$ GEPT; $\mathrm{T} 3=$ basal ration $+0.15 \%$ GEPT; $\mathrm{T} 4=$ basal ration $+0.2 \%$ GEPT. 
tion in the jejunum and ileum (Table 2). These results were caused by nutrient competition in the gastrointestinal tract between LAB and pathogenic bacteria in utilizing glucomannan as "food source". A previous study (Li et al., 2009) indicated that the addition of $220 \mathrm{mg} / \mathrm{kg}$ Astragalus polysaccharides (APS) increased Lactobacilli and Bifidobacteria, and decreased Escherichia coli in the ileum of broiler chickens at 21 and 42 days of age. Similarly, Rebole et al. (2010) stated that supplementation of inulin at $20 \mathrm{~g} / \mathrm{kg}$ feed increased Lactobacilli and Bifidobacteria in the ileum of 35-day old broiler chickens. The mechanism of how glucomannan could modulate the intestinal milleu to produce a better condition or improve the balance of intestinal bacteria was described in the following explanation. The products of glucomannan breakdown by $\beta$-mannanase and $\beta$-glucanases in the caeca were utilized by LAB as an energy source for growth. The linkages of glucomannan could be hydrolyzed by endo-1,4- $\beta$-mannanases and endo- $\beta$ glucanases (Mikkelson et al., 2013). Prebiotic glucomannan consisted of D-glucose monomers and D-mannose units linked by $\beta$-1,4-glycosidic bonds (Tester and AlGhazzewi, 2013). Chauhan et al. (2012) stated that some strains of LAB, such as Bacillus, produced $\beta$-mannanase, an enzyme that able to breakdown $\beta-1.4$ bonds between glucose and mannose or mannose and mannose. Betaglucanases hydrolyzed glucose to glucose $\beta$ linkages (Mikkelson et al., 2013). Carbohydrate prebiotic could be fermented by lactic acid bacteria to get energy utilizing endogenous carbon sources as final electron acceptor but not oxygen (Mokoena, 2017).

Lactic acid bacteria (LAB) population was lower and Coliform counts were higher with supplementation of GEPT at the levels of $0.15 \%$ (T3) and $0.2 \%$ (T4) compared to T1 treatment (Table 2). Bogusławska-Tryk et al. (2015) stated that the positive effect of prebiotic on ileal and caecal microflora was dose-dependent. Glucomannan is a water-soluble non-starch polysaccharide (NSP) (Zhang et al., 2005). Increasing prebiotic level containing water-soluble NSP had a negative effect on intestinal microflora because the fermentative product of soluble NSP could be used as an energy source for anaerobic microbes such as pathogen bacteria, and lead to the increase in E. coli and the decrease in Lactobacillus and Bifidobacteria (Sethy et al., 2015; Kermanshahi et al., 2018). In case of the present study, the higher level of glucomannan supplementation in T3 and T4 with watersoluble NSP contents increased Coliform counts and lowered LAB population.

The growth of LAB was highly dependent on the fermentable carbohydrates derived from glucomannan. It had been previously described that prebiotic substrate, such as glucomannan, could be fermented by gastrointestinal LAB into SCFA and lactic acid that decreased the intestinal $\mathrm{pH}$. The low intestinal $\mathrm{pH}$ (jejunum $\mathrm{T} 0=5.21$ vs. $\mathrm{T} 2=5.04$; ileum $\mathrm{T} 0=6.32$ vs. $\mathrm{T} 2=6.08$ ) was the evidence indicating the effect of glucomannan fermentation due to GEPT supplementation. Pourabedin \& Zhao (2015) stated that beneficial bacteria in the gastrointestinal tract fermented prebiotic into SCFA especially acetic acid, butyric acid, and propionic acid. Short chain fatty acids brought about the lower potential hydrogen $(\mathrm{pH})$ of intestinal so that Coliform could not survive well in the acidic condition. Bogusławska-Tryk et al. (2015) indicated that lignocellulose supplementation up to $0.5 \%$ increased the amount of lactic acid and SCFA, decreased the $\mathrm{pH}$ of the ileum and E. coli population. The similar finding reported by Markovi et al. (2009) that dietary inclusion of $0.2 \%$ MOS decreased $\mathrm{pH}$ of the ileum compared to the control of 6.81 to $6.50 \%$ MOS-fed broiler. However, the growth of pathogenic bacteria, such as E. coli, was optimal at $\mathrm{pH}$ of $7.0-7.5$, whereas $\mathrm{pH}$ below 7 might decrease their growth (Philip et al., 2018). In contrast to Coliform, the low $\mathrm{pH}$ stimulated the growth of lactic acid bacteria (Table 2). The phenomenon found in the present study was supported by the report of Wright \& Axelsson (2011) that the growth of lactic acid bacteria was optimal at the $\mathrm{pH}$ range of 5-6.

In addition to the nutrient competition, the mechanism of the increase in $\mathrm{LAB}$ and the decrease in Coliform due to the supplementation of GEPT was also attributable to the competitive exclusion (CE) between $\mathrm{LAB}$ and pathogenic bacteria. Mannose production due to the fermentation of glucomannan by endogenous LAB could outwit the attachment of pathogenic bacteria in the intestinal lumen. Yang et al. (2009) and Saeed et al. (2017) stated that mannose did not only avoid pathogenic bacteria fimbriae type- 1 attaching on the epithelial surface but also shooed pathogenic bacteria away from the intestinal wall. Mannose might replace lectin that acted as a receptor of pathogenic bacteria, and then pathogen bound to mannose molecule component passed through the gastrointestinal tract along with the dropping of excreta without colonization (Pourabedin \& Zhao, 2015; Saeed et al., 2017). Competitive exclusion indicated the ability of LAB in colonizing and increasing the attachment competition to the intestinal mucous membrane. This mechanism could prevent pathogenic bacteria, such as E. coli, attacking intestinal lumen and colonization, and thus brought about the improvement of the balance of intestinal microflora (Bukhari et al., 2017).

\section{Body Resistance and Growth Performance}

Relative weights of bursa of fabricius and spleen were not influenced by feeding dietary supplementation of GEPT (Table 3). The present result was supported by the previous studies that prebiotic inclusion of MOS had no significant effect on the weight of the lymphoid organ of broiler (Houshmand et al., 2012). The weight of bursa fabricius in birds given diet supplemented with GEPT (T1-T4) was ranging from $0.201 \%$ to $0.209 \%$. The status of body resistance of broiler was categorized high when the relative weight of bursa fabricius was above $0.2 \%$ (Sellaoui et al., 2012). In respect to body resistance, the profile of bursa fabricius reflected the adaptability of the chickens to either inside or outside the body condition. In case of the present study, adaptability was closely related to bacterial balance that the control group (T0) had the highest population of Coliform with the lowest BAL counts. Therefore, it could be assumed that 
the control group chickens suffered from the unfavourable intestinal condition due to the high population of Coliform.

In case of spleen weight, no significant effect of GEPT supplementation (T1-T4) was found (Table 3). Even though there was no change in spleen weight when the birds were fed diet supplemented with GEPT, their health seems to be better, as was indicated by the lower $\mathrm{H} / \mathrm{L}$ ratio. Pathogenic bacteria such as E. coli could enter to colonize and infect spleen (Mellata et al., 2010). Escherichia coli infection in chicken caused the increase in spleen weight (Shini et al., 2008). However, the present result was different from those previously reported as described above. Also, it was inconsistent when compared to Fajrih et al. (2014) that crossbred local chickens given control diet, without prebiotic inulin of dahlia tuber, had higher spleen weight. The higher spleen weight could be associated with the infected state of pathogenic bacteria and stimulated the spleen to work harder which followed by the increased weight and size. Therefore, the different "nutrient" sources derived from inulin and glucomannan for the fermentative activity of intestinal $\mathrm{LAB}$ might be the principle cause in relation to spleen growth and function.

Anticipation mechanism of bursa fabricius and spleen against external negative influences is mainly related to the high population of intestinal pathogenic bacteria that caused the unfavorable condition in broiler chickens. It can be associated with the higher $\mathrm{H} / \mathrm{L}$ ratio as an indicator of health status in chickens. The H/L ratio is closely related to bursa fabricius as a site of lymphocyte formation that played a role in the immune system against stress condition. The present results showed that broiler chickens given diet supplemented with GEPT at all levels (Table 3) had lower $\mathrm{H} / \mathrm{L}$ ratio than control treatment. The result was similar to the report of Fajrih et al. (2014) that the inclusion of inulin up to $1.17 \%$ lowered $\mathrm{H} / \mathrm{L}$ ratio than control. The lower $\mathrm{H} / \mathrm{L}$ ratio induced by GEPT inclusion indicated that the bird was in a favorable condition or suffered low stress (Hosseini et al., 2016). The healthier and better body resistance could be related with the increase in LAB and the decrease in Coliform due to the supplementation of GEPT in T1 to T4, as compared to control group (T0) (Table 2). Since broilers fed the increased levels of GEPT in T2 to T4 had higher body resistance, there was no mortality was found in these groups. In contrast, broilers in groups T0 and $\mathrm{T} 1$ showed a $3.12 \%$ mortality in each group.

Dietary supplementation of GEPT did not significantly affect BWG, FC, and FCR whereas broiler chickens with $0.1 \%-0.2 \%$ GEPT had no mortality. However, the pattern of body weight gain was similar to that of bursa fabricius and spleen weights that GEPT supplementation had no statistically different effect. The present result was supported by Sarangi et al. (2016) that the addition of prebiotic MOS in broiler had no significant effect on body weight gain. Elrayeh \& Yildiz (2012) also reported that prebiotics inulin and $\beta$-glucan did not affect feed consumption and FCR.

\section{CONCLUSION}

Dietary inclusion of glucomannan extracted from porang tuber at $0.1 \%$ improves body resistance of broiler chickens indicated by lower $\mathrm{H} / \mathrm{L}$ ratio, supported by the increase in lactic acid bacteria population and the decrease in Coliform population, without any negative effects on lymphoid organs and growth performance.

\section{CONFLICT OF INTEREST}

The authors declare that there is no conflict of interest with any financial support, personal, or relationships with other people or organization related to the material used and discussed in the manuscript.

\section{ACKNOWLEDGEMENT}

The author would like to thank Ministry of Agriculture, the Republic of Indonesia for the financial support of this study provided via the Program Master Dalam Negeri Scholarship with contract No. 587/Kpts/ KP.320/10/2015. Special thank is also addressed to Prof. Dr. Ir. Eni Harmayani, M.Sc., Faculty of Agricultural Technology, Universitas Gadjah Mada, for facilitating extraction of porang glucomannan.

\section{REFERENCES}

Bindels, L. B., N. M. Delzenne, P. D. Cani, \& J. Walter. 2015. Towards a more comprehensive concept for prebiotics. Nat. Rev. Gastroenterol. Hepatol. 12:303-310. https://doi. org/10.1038/nrgastro.2015.47

Bogusławska-Tryk, M., R. Szymeczko, A. Piotrowska, K. Burlikowska, \& K. Slizewska. 2015. Ileal and cecal microbial population and short-chain fatty acid profile in broiler chickens fed diets supplemented with lignocellulose. Pak. Vet. J. 35:212-216.

Bolton, W. 1967. MAFF Bulletin. No.174. Poultry Nutrition. HMSO, London.

Bozkurt, M., K. Kucukyilmaz, A. U. Catli, M. Cinar, E. Bintas, \& F. Coven. 2012. Performance, egg quality, and immune response of laying hens fed diets supplemented with mannan-oligosaccharide or an essential oil mixture under moderate and hot environmental conditions. Poult. Sci. 91:1379-1386. https://doi.org/10.3382/ps.2011-02023

Bukhari, S. M., M. Iram, T. Lijie, M. Sunting, H. L. Mang, G. Abbas, I. Baboo, \& Y. Li. 2017. Coherence and colonization characteristics of recombinant Lactobacillus under simulated gastric conditions within chicken GI tract and its impact on chicken growth. Pak. Vet. J. 37:381-386.

Chauhan, P. S., N. Puri, P. Sharman, \& N. Gupta. 2012. Mannasases: microbial sources, production, properties and potential biotechonological applications. Appl. Microbiol. Biotechnol. 93: 1817-1830. https://doi.org/10.1007/ s00253-012-3887-5

Elrayeh, A. S. \& G. Yildiz. 2012. Effects of inulin and $\beta$-glucan supplementation in broiler diets on growth performance, serum cholesterol, intestinal length, and immune system. Turk. J. Vet. Anim. Sci. 36:388-394.

Fajrih, N., N. Suthama, \& V. D. Yunianto. 2014. Body resistance and productive performances of crossbred local chicken fed inulin of Dahlia tubers. Med. Pet. 37:108-114. https:// doi.org/10.5398/medpet.2014.37.2.108

Fardiaz, S. 1993. Analisis Mikrobiologi Pangan. Raja Grafindo Persada, Jakarta. 
Gross, W. B. \& H. S. Siegel. 1983. Evaluation of heterophil/lymphocyte ratio as a measure of stress in chickens. Avian Dis. 27:972-979. https://doi.org/10.2307/1590198

Harmayani, E., V. Aprilia, \& Y. Marsono. 2014. Characterization of glucomannan from Amorphophallus oncophyllus and its prebiotic activity in vivo. Carbohydr. Polym. 112:475-479. https://doi.org/10.1016/j.carbpol.2014.06.019

Hosseini, S. M., H. Nazarizadeh, S. Ahani, \& M. V. Azghandi. 2016. Effects of mannan oligosaccharide and Curcuma xanthorrhiza essential oil on the intestinal morphology and stress indicators of broilers subjected to cyclic heat stress. Arch. Anim. Breed. 59:285-291. https://doi.org/10.5194/ aab-59-285-2016

Houshmand, M., K. Azhar, I. Zulkifli, M. H. Bejo, \& A. Kamyab. 2012. Effects of prebiotic, protein level, and stocking density on performance, immunity and stress indicators of broilers. Poult. Sci. 91:393-401. https://doi. org/10.3382/ps.2010-01050

Kermanshahi, H., M. D. Shakouri, \& A. Daneshmand. 2018. Effect of non-starch polysaccharides in semi-purified diet on performance, serum metabolites, gastrointestinal morphology and microbial population of male broiler chickens. Livest. Sci. 214:93-97. https://doi.org/10.1016/j. livsci.2018.04.012

Kim, G. B., Y. M. Seo, C. H. Kim, \& I. K. Paik. 2011. Effect of dietary prebiotic supplementation on the performance, intestinal microflora, and immune response of broilers. Poult. Sci. 90:75-82. https://doi.org/10.3382/ps.2010-00732

Kohl, K. D. 2012. Diversity and function of the avian gut microbiota. J. Comp. Phys. B. 182:591-602. https://doi. org/10.1007/s00360-012-0645-Z

Li, S. P., X. J. Zhao, J. Y. Wang. 2009. Synergy of Astragalus polysaccharides and probiotics (Lactobacillus and Bacillus cereus) on immunity and intestinal microbiota in chicks. Poult. Sci. 88:519-25. https://doi.org/10.3382/ps.2008-00365

Mellata, M., K. Ameiss, H. Mo, \& R. Curtiss. 2010. Characterization of the contribution to virulence of three large plasmids of avian pathogenic Escherichia coli $x 7122$ (O78:K80:H9). Infect. Immun. 78:1528-1541. https://doi. org/10.1128/IAI.00981-09

Markovi, R., D. Sefer, M. Krstic, \& B. Petrujkic. 2009. Effect of different growth promoters on broiler performance and gut morphology. Arch. Med. Vet. 41:163-169. https://doi. org/10.4067/S0301-732X2009000200010

Mateova, S., J. Saly, M. Tuckova, J. Koscova, R. Nemcova, M. Gaalova, \& D. Baranova. 2008. Effect of probiotics, prebiotics and herb oil on performance and metabolic parameters of broiler chickens. Medycyna Wet. 64:294-297.

Meimandipour, A., A. Soleimanifarjam, K. Azhar, M. HairBejo, M. Shuhaimi, Leyla Nateghi, \& A. M. Yazid. 2011. Age effects on short chain fatty acids concentrations and $\mathrm{pH}$ values in the gastrointestinal tract of broiler chickens. Arch. Geflugelk. 75:164-168.

Mikkelson, A., H. Maaheimo, \& T. K. Hakala. 2013. Hydrolysis of konjac glucomannan by Trichoderma reesei mannanase and endoglucanases Cel7B and Cel5A for the production of glucomannooligosaccharides. Carbohydr. Research. 372:60-68. https://doi.org/10.1016/j.carres.2013.02.012

Mokoena, M. P. 2017. Lactic acid bacteria and their bacteriocins: classification, biosynthesis and appliccations against uropatogens. Mol. 22:1-13. https://doi.org/10.3390/ molecules22081255

NRC. 1994. Nutrient Requirements of Poultry. $9^{\text {th }}$ revised ed. National Academic Press, Washington DC.

Philip, P., D. Kern, J. Goldmanns, F. Seiler, A. Schulte, T. Habicher \& J. Buchs. 2018. Parallel substrate supply and
$\mathrm{pH}$ stabilization for optimal screening of E. coli with the membrane-based fed-batch shake flask. Microb. Cell Fact. 17:1-17. https://doi.org/10.1186/s12934-018-0917-8

Pourabedin, M. \& Z. Zhao. 2015. Prebiotics and gut microbiota in chickens. FEMS Microbiol. Lett. 362:1-8. https://doi. org/10.1093/femsle/fnv122

Pourabedin, M, L. Guan \& X. Zhao. 2015. Xylo-oligosaccharides and virginiamycin differentially modulate gut microbial composition in chickens. Microbiome 3:1-12. https://doi. org/10.1186/s40168-015-0079-4

Rebole, A., L. T. Ortiz, M. L. Rodríguez, C. Alzueta, J. Treviño, \& S. Velasco. 2010. Effects of inulin and enzyme complex, individually or in combination, on growth performance, intestinal microflora, cecal fermentation characteristics, and jejunal histomorphology in broiler chickens fed a wheat- and barley-based diet. Poult. Sci. 89:276-286. https://doi.org/10.3382/ps.2009-00336

Ruminska, E., A. Koncicki, \& T. Stenzel. 2008. Structure and function of the avian immune system in birds. Medycyna Wet. 64:265-268.

Sarangi, N. R., L. K. Babu,A. Kumar, C. R. Pradhan, P. K. Pati, \& J. P. Mishra. 2016. Effect of dietary supplementation of prebiotic, probiotic, and synbiotic on growth performance and carcass characteristics of broiler chickens. Vet. World. 9:313-319. https://doi.org/10.14202/vetworld.2016.313-319

Saeed, M., F. Ahmad, M. A. Arain, M. E. Abd El-Hack, M. Emam, Z. A. Butto, \& A. Moshaveri. 2017. Use of mannanoligosaccharides (MOS) as a feed additive in poultry nutrition. J. World Poult. Res. 7:94-103.

Sellaoui, S., N. Alloui, S. Mehenaoui, \& S. Djaaba. 2012. Evaluation of immune status of the chicken using morphometry and histology of the bursa of fabrisius. J. Vet. Adv. 2:440-443.

Sethy, K., S. K. Mishra, P. P. Mohanty, J. Agarawal, P. Meher, D. Satapathy , J. K. Sahoo, S. Panda, \& S. M. Nayak. 2015. An overview of non starch polysaccharide. J. Anim. Nutr. Physiol. 1:17-22.

Shini, S., P. Kaiser, A. Shini, \& W. L. Bryden. 2008. Biological response of chickens (Gallus gallus domesticus) induced by corticosterone and a bacterial endotoxin. Comp. Biochem. Physiol. B. Biochem. Mol. Biol. 149:324-333. https://doi. org/10.1016/j.cbpb.2007.10.003

Steel, R. G. D, \& J. H. Torrie. 1991. Prinsip dan Prosedur Statistika Suatu Pendekatan Biometrik. $2^{\text {nd }}$ ed. Terjemahan. PT Gramedia Pustaka Tama, Jakarta.

Tester, R. F. \& F. H. Al-Ghazzewi. 2013. Mannans and health, with a special focus on glucomannans. Food Res. Int. 50:384-391. https://doi.org/10.1016/j.foodres.2012.10.037

Wright, A. V. \& L. Axelsson. 2011. Lactic Acid Bacteria: An Introduction. In: S. Lahtinne, S. Salminen, A. Von Wright \& A. Ouwehand, Eds., Lactic Acid Bacteria: Microbiological and Functional Aspects. CRC Press, London. pp. 1-17. https://doi.org/10.1201/b11503

Yang, Y., P. A. Iji \& M. Choct. 2009. Dietary modulation of gut microflora in broiler chickens: a review of the role of size kinds of altrnatives to in-feed antibiotics. Worlds Poult. Sci. J. 65:97-114. https://doi.org/10.1017/S0043933909000087

Yanuriati, A., D.W. Marseno, Rochmadi, \& E. Harmayani. 2017. Characteristics of glucomannan isolated from fresh tuber of Porang (Amorphophallus muelleri Blume). Carbohydr. Polym. 156:56-63. https://doi.org/10.1016/j. carbpol.2016.08.080

Zhang, Y.Q., B. J. Xie, \& X. Gan. 2005. Advance in the applications of konjac glucomannan and its derivatives, Carbohydr. Polym. 60:27-31. https://doi.org/10.1016/j. carbpol.2004.11.003 